\title{
Poznańska leksyka regionalna w świetle koncepcji geografii myślenia Richarda E. Nisbetta
}

\section{Poznań regional vocabulary according to Richard E. Nisbett's concept of thinking geography}

\author{
Anna Piotrowicz, Małgorzata Witaszek-Samborska \\ INSTYTUT FILOLOGII POLSKIEJ, UNIWERSYTET IM. ADAMA MICKIEWICZA \\ W POZNANIU Ul. A. FREDRY 10, 61-701 POZNAŃ \\ ape@amu.edu.pl, msamborska@tlen.pl
}

\begin{abstract}
This article is an attempt to use the Richard Nisbett's observations (the differences in the structure of parts of speech in the languages of East and West) to the Polish language and Poznan regional vocabulary. The analysis applies only to the lexical system, rather than the structure of words in texts. Studies confirm that the Polish language lexical system - both general and regional - is close to the languages of the West.
\end{abstract}

Keywords: the geography of thought - lexical regionalisms - parts of speech

\section{Wprowadzenie - koncepcja geografii myślenia}

Język a myślenie - to kwestia właściwie nieustannie intrygująca badaczy (w szczególności z kręgów humanistycznych), a wzrost popularności kierunków kognitywnych przyczynił się $\mathrm{w}$ ostatnich latach do bardzo żywego ponownie zainteresowania się tą tematyką i intensywnego zgłębiania problemu wzajemnych relacji tych dwóch jakże istotnych dla człowieka fenomenów. Amerykański psycholog Richard E. Nisbett w książce Geografia myślenia (2011) gromadzi dowody (na podstawie dotychczasowego dorobku uczonych Zachodu i Wschodu oraz własnych badań) na to, że procesy poznawcze człowieka, sposób jego myślenia i wynikające $\mathrm{z}$ tego relacje społeczne $\mathrm{w}$ dużej mierze uwarunkowane są terytorialnie, a co za tym idzie - kulturowo. Wskazuje dwa odmienne podejścia do świata, charakterystyczne z jednej strony dla ludzi Zachodu, z drugiej zaś - Wschodu. W swej książce precyzuje, że ludźmi Zachodu 
nazywa przedstawicieli kultury europejskiej (na przykładzie Wielkiej Brytanii, Niemiec, Holandii, Belgii, Francji, Hiszpanii, Portugalii, Włoch), ludźmi Wschodu, przykładowo, mieszkańców Chin, Japonii i Korei Południowej, zaś wśród Amerykanów wyróżnia osoby pochodzenia europejskiego (ludzi rasy czarnej, białej i Latynosów) oraz azjatyckiego. Sam podkreśla pewne uproszczenie zawarte w takim podziale, ale uważa go za uzasadniony ze względu na wiele ogólnych prawidłowości. Hipotetycznie zakłada, że wywodzące się od czasów starożytności różnice poznawcze między mieszkańcami Wschodu i Zachodu występują także współcześnie. W najogólniejszym zarysie dotyczą one:

- $\quad$ wzorców uwagi i percepcji, tzn. ludzie Wschodu koncentrują się bardziej na środowisku i zależnościach między zjawiskami, a Zachodu - na obiektach;

- podstawowych założeń na temat budowy świata (według mieszkańców Wschodu tworzą go głównie substancje, według mieszkańców Zachodu - obiekty);

- przekonań związanych z możliwością kontrolowania otoczenia (zdecydowanie bardziej wierzą $\mathrm{w}$ tę możliwość przedstawiciele Zachodu niż Wschodu);

- preferowanych wzorców wyjaśniania zdarzeń (mieszkańcy Zachodu koncentrują się na obiektach i ich atrybutach, a Wschodu - holistycznie na szerokiej sieci powiązań z otoczeniem);

- $\quad$ sposobu organizowania świata (ludzie Zachodu kładą nacisk na kategorie i klasyfikacje, a Wschodu - na relacje);

- $\quad$ stosowania zasad logiki formalnej (do czego bardziej skłonni są mieszkańcy Zachodu);

- $\quad$ stosowania podejścia dialektycznego (ludzie Wschodu w sprzecznościach szukają Drogi Środka, a Zachodu - wybierają tę, którą uznają za słuszną) (Nisbett 2011: 46-47).

Konsekwencją tych różnic są odmienne postawy w procesie komunikowania się. „Na Zachodzie ludzie uczą swoje dzieci roli „nadawcy”, odpowiedzialnego za precyzyjne formułowanie myśli i wypowiadanie zdań w taki sposób, aby słuchacz bez trudu je zrozumiał - co więcej, zrozumiał je niezależnie od kontekstu. Jeżeli komunikacja nie przebiega prawidłowo, to jest to wina mówiącego. Natomiast w Azji dzieci uczą się roli „odbiorcy”, co oznacza, że odpowiedzialność za zrozumienie tego, co się mówi, spada na słuchacza" (Nisbett 2011: 57-58).

$\mathrm{Z}$ językoznawczego punktu widzenia Nisbett stawia interesujące pytania dotyczące sposobu porządkowania wiedzy, typu: „Dlaczego dzieci na Zachodzie szybciej poznają rzeczowniki niż czasowniki, podczas gdy na Wschodzie jest odwrotnie? Dlaczego mieszkańcy Azji Wschodniej grupują obiekty i zdarzenia ze względu na ich wzajemne relacje, a mieszkańcy Zachodu - ze względu na ich kategorie?” (Nisbett 2011: 15). Panuje dość powszechne przekonanie przedstawicieli Zachodu, że w procesie akwizycji zarówno rodzimego, jak i obcego języka łatwiej jest przyswoić sobie rzeczowniki. Wystarczy bowiem zapamiętać zbiór prototypowych 
właściwości, które wykorzystuje się następnie do nazywania kolejnych obiektów danej kategorii. Trudnością w przyswajaniu czasowników jest ich częstsza wieloznaczność, wynikająca $\mathrm{z}$ konieczności wskazywania różnorodnych relacji łączących obiekty z działaniami. Tymczasem okazuje się, że mieszkańcom Wschodu latwiej jest przyswajać sobie czasowniki. Wynika to z kilku przyczyn:

- w językach wschodnioazjatyckich czasowniki są bardziej wyeksponowane niż $w$ językach zachodnioeuropejskich (w strukturze zdania zajmują zwykle pozycję inicjalną lub finalną);

- $\mathrm{w}$ procesie akwizycji języka dziecko w krajach zachodnioeuropejskich szybciej przyswaja sobie rzeczowniki, gdyż rodzice „mają obsesję na punkcie rzeczowników, w rozmowie ze swoimi dziećmi pokazują obiekty, nazywają je i opowiadają o ich cechach" (Nisbett 2011: 114), podczas gdy rodzice z Azji Wschodniej w zabawie z dziećmi kładą nacisk na aranżowanie sytuacji społecznych i wskazują im relacje między ludźmi, ucząc na przykład zachowań grzecznościowych;

- u dzieci z Europy Zachodniej konsekwencją nazywania obiektów jest poznawanie kategorii, do których należą obiekty o tych samych właściwościach, a także konstruowanie zbiorów tych właściwości, co z kolei pozwala tworzyć kolejne kategorie;

- dzieci ze Wschodu później niż dzieci z Zachodu uczą się klasyfikowania obiektów, wcześniej zaś - planowania działań nastawionych na osiągnięcie celu.

Richard E. Nisbett wymienia jeszcze jedną przyczynę takiego stanu rzeczy, mianowicie obecność w języku angielskim gramatycznych wykładników generycznych bądź jednostkowych znaczeń rzeczowników (w postaci przedimków: nieokreślonego $a$ oraz określonego the), a ich brak w języku chińskim i innych językach sinickich, ale przedimków tych brak też $\mathrm{w}$ języku polskim, dlatego nie mogą one stanowić przedmiotu niniejszych rozważań (Nisbett 2011: 113-115).

Kolejne pytanie stawiane przez amerykańskiego badacza brzmi: „Czy to, co wiemy na temat organizowania wiedzy, wynika z faktu, że języki zachodnie skłaniają do używania rzeczowników, a w konsekwencji do tworzenia kategorii obiektów, a wschodnie zachęcają do stosowania czasowników, czego skutkiem jest przywiązywanie większej wagi do relacji? [...] Dla mieszkańców świata zachodniego to Ja wykonuje działanie, dla mieszkańców Wschodu działanie jest czymś, co się podejmuje $\mathrm{w}$ harmonii z innymi albo co wynika z interakcji Ja z siłami pola. Język odzwierciedla owo odmienne podejście do sprawczości" (Nisbett 2011: 117-119). Nisbett podkreśla, że różnica w opisywaniu świata według kategorii (Zachód) bądź relacji (Wschód) nie tkwi w strukturze języka, tylko $\mathrm{w}$ procesach poznawczych determinowanych czynnikami kulturowymi, w których przebiega ontogeneza użytkowników danego języka. Różnice strukturalne między językami Wschodu i Zachodu są zatem konsekwencją owych odmiennych procesów poznawczych. 


\section{Język polski w świetle koncepcji Richarda E. Nisbetta}

Poza obszarem swoich zainteresowań Nisbett pozostawił języki Europy Wschodniej i Środkowej. W odniesieniu do języka polskiego pierwszą próbę weryfikacji koncepcji amerykańskiego psychologa podjął Michał Szczyszek w artykule Stowotwórcze przejawy wspólnoty komunikacyjnej (na przykładzie języka polskiego) (Szczyszek, w druku). W konkluzji autor stwierdza, że polskie słowotwórstwo wykazuje „przechył rzeczownikowy”, „co uwidacznia się podczas analizy modeli słowotwórczych: a) więcej jest rzeczownikowych kategorii słowotwórczych niż kategorii słowotwórczych czasownika, b) więcej jest rzeczownikowych formantów słowotwórczych niż formantów tworzących czasowniki, c) formanty rzeczownikowe są pod względem semantycznym bardziej precyzyjne i jednoznaczne, a formanty czasownikowe - mają znaczenie raczej ogólne i - na pewno wieloznaczne. Można by zatem przyjąć, że polskojęzyczna wspólnota komunikacyjna wykazuje obserwowalne na poziomie słowotwórczym, a więc $\mathrm{w}$ zakresie jednej $\mathrm{z}$ najważniejszych możliwości poznania konceptualizacji i językowego kategoryzowania świata - tendencje zbliżania do kultury Zachodu - zgodnie z koncepcją R.E. Nisbetta” (Szczyszek, w druku). Jednak w podsystemie słowotwórczym polszczyzny daje się też zaobserwować - jak pisze autor artykułu - pewien „wschodni refleks" (stosunkowo dużą liczbę derywatów czasownikowych).

Wyniki badań z zakresu polskiego językoznawstwa statystycznego wskazują również na to, że dla użytkowników naszego języka charakterystyczne jest przedmiotowe, kategorialne postrzeganie rzeczywistości. Jadwiga Sambor (Sambor 2001), na podstawie prac Zygmunta Saloniego (Saloni 1988), Ireny Kamińskiej-Szmaj (KamińskaSzmaj 1990), Haliny Zgółkowej (Zgółkowa 1987) i Marii Zarębiny (Zarębina 1985) podaje procentowe udziały części mowy w słowniku i tekstach (pisanych oraz mówionych). Przedstawiają się one następująco: w systemie leksykalnym polszczyzny przeważają rzeczowniki $(54,9 \%)$ nad przymiotnikami (19,6\%), czasownikami (19,5\%), przysłówkami $(4,1 \%)$ oraz pozostałymi częściami mowy (1,9\%). W tekstach znacznie zmniejsza się różnica między udziałem rzeczowników i czasowników. W tekstach pisanych rzeczowniki to 30,1\%, czasowniki 15,1\%, zaś w mówionych rzeczowniki to $18 \%$ (Zgółkowa 1987) bądź 21,6\% (Zarębina 1985), a czasowniki 20,2\% (Zgółkowa 1987) lub 19,1\% (Zarębina 1985). Udział pozostałych części mowy $\mathrm{w}$ tekstach pisanych to: przymiotniki 17,9\%, przysłówki 4,6\%, inne 32,3\%, a w tekstach mówionych: przymiotniki między $4,4 \%$ a $5,4 \%$, przysłówki $7 \%$ a $7,9 \%$, inne $46 \%$ a $50,4 \%$. Tak znaczny udział w tekstach części mowy określanych tu jako ,inne” wynika z faktu, że obejmują one przede wszystkim wyrazy o funkcji gramatycznej, osiągające najwyższą frekwencję.

$\mathrm{O}$ ile zatem na poziomie systemu leksykalnego potwierdza się w polszczyźnie opisane przez Nisbetta typowe dla języków Zachodu przedmiotowe widzenie świata, o tyle na poziomie tekstowym przewaga 
rzeczowników utrzymuje się w odmianach pisanych, choć nie jest już tak wyrazista, a w odmianach mówionych różnica ta wręcz się zaciera (od $18 \%$ do $21,6 \%$ to rzeczowniki, a od $19,1 \%$ do $20,2 \%$ - czasowniki).

\section{Poznańska leksyka regionalna w świetle koncepcji Richarda E. Nisbetta}

Niniejszy artykuł stanowi pierwszą próbę przeniesienia koncepcji geografii myślenia Richarda E. Nisbetta na grunt badań nad regionalnymi odmianami polszczyzny. Zastrzec należy, że badania nasze ograniczamy do płaszczyzny słownikowej, a nie tekstowej, terytorialnie zaś wyłącznie do gwary miejskiej Poznania. Mają one zatem charakter wstępny, a wynikające $\mathrm{z}$ nich wnioski są ostrożne i nie mogą być traktowane jako uniwersalne.

Podstawa materiałowa niniejszych analiz to jednostki leksykalne ze Słownika gwary miejskiej Poznania (Gruchmanowa, Walczak (red.) 1999). Zaznaczyć trzeba, że badanych przez nas jednostek jest więcej niż wyrazów hasłowych, bowiem każde znaczenie wyrazu hasłowego uznajemy za odrębną jednostkę leksykalną (por. Bańko 2002: 26).

W strukturze leksyki poznańskiej, podobnie jak w systemie leksykalnym polszczyzny ogólnej, przeważają rzeczowniki - jest ich 1837 (w tym 106 wyrażeń rzeczownikowych). Pozostałe części mowy to: 1134 czasowniki (w tym 281 zwrotów i 79 fraz), 265 przymiotników (w tym 5 wyrażeń określających o funkcji przymiotnika), 125 przysłówków (w tym 51 wyrażeń określających o funkcji przysłówka), 33 zaimki, 33 wykrzykniki, 14 modulantów, 11 przyimków i 2 spójniki. Zatem procentowy udział poszczególnych części mowy w strukturze regionalnej leksyki poznańskiej przedstawia się następująco:

\begin{tabular}{|c|l|c|c|c|c|c|c|c|}
\hline rzecz. & czas. & przym. & przysł. & zaimki & wykrz. & modul. & przyim. & spójn. \\
\hline $53,2 \%$ & $32,8 \%$ & $7,7 \%$ & $3,6 \%$ & $0,95 \%$ & $0,95 \%$ & $0,4 \%$ & $0,3 \%$ & $0,1 \%$ \\
\hline
\end{tabular}

W porównaniu z polszczyzną ogólną udział rzeczowników w strukturze słownictwa regionalnego jest podobny $(54,9 \% \mathrm{w}$ polszczyźnie ogólnej - 53,2\% w poznańskiej). Jednak w zakresie czasowników rysują się tu znaczne różnice. W strukturze polszczyzny ogólnej czasowniki stanowią 19,5\%, co zbliża język polski do struktury opisanej przez Richarda E. Nisbetta grupy języków zachodnioeuropejskich. Tymczasem w polszczyźnie poznańskiej udział czasowników jest znacznie większy - prawie 33\%, co można by - odwołując się do wcześniej już przytoczonych słów Michała Szczyszka (Szczyszek, w druku) uznać za „refleks wschodni”.

Mimo owego „wschodniego refleksu” przewagę rzeczowników nad czasownikami w gwarze miejskiej Poznania wciąż można uznać za znaczącą. W świetle koncepcji Nisbetta świadczy to o tym, że użytkownicy tej gwary reprezentują postawę poznawczą charakterystyczną dla kultury Zachodu. 
Dodatkowym czynnikiem wspierającym kształtowanie się okcydentalnego charakteru owej postawy oraz jej przejawów na płaszczyźnie językowej jest wielowiekowa interferencja mentalno-lingwistyczna między kulturą i polszczyzną mieszkańców Poznania a kulturą i językiem Niemców, szczególnie nasilona w okresie zaborów.

Cechy przypisywane prototypowym obiektom wyodrębnianym w rzeczywistości pozajęzykowej przez poznaniaków pozwalają przypisać te obiekty do różnorodnych kategorii, które poniżej wymieniamy, uwzględniając ich liczebność. Zastrzec należy, że jak w każdej klasyfikacji semantycznej, zakresy poszczególnych kategorii nie stanowią zbiorów rozłącznych - pewne jednostki leksykalne należą do więcej niż jednej kategorii (por. angryst 'agrest' - „roślina” i „pożywienie”, hulajpeta 'hulajnoga' - ,pojazd” i ,zabawka”), ale ze względu na przejrzystość opisu dokonujemy arbitralnych klasyfikacji. Kategorie te to:

osoby - 454 (np. bulaj 'grubas', choróbka 'chora osoba; także ktoś skłonny do chorób', dziadzia 'dziadek', flizkarz 'rzemieślnik układający płytki ceramiczne', ginolicha 'dziewczyna, kobieta wysokiego wzrostu', kletuśnica 'plotkarka', tagol 'człowiek bardzo wysoki, drągal', motorowa 'kobieta motorniczy', październik 'mizerota, ktoś niewysoki, szczupły', szkiet 'policjant, w okresie PRL-u milicjant');

sprzęty (narzędzia, naczynia itp.) - 196 (np. brecha 'łom', chochelka 'mała łyżka wazowa', haczka 'motyka', haczyk 'pogrzebacz', kasta 'skrzynia, skrzynka', knara 'pistolet, karabin', kopystka 'drewniana łyżka lub łopatka do mieszania i nakładania potraw', kwirlejka 'mątewka', majsel 'przecinak do metalu', skurzawka 'ściereczka do kurzu');

pożywienie - 192 (np. grycha 'bułka', kamsztyk 'karkówka', kaszak 'kaszanka', knobloszek 'kiełbasa parówkowa', leberka 'wątrobianka, pasztetowa', nudle 'makaron', poznańska babka 'rodzaj ciasta - babka piaskowa', skrzyczka 'skwarka', szneka 'okrągła drożdżówka spiralnie skręcona, w kształcie muszli ślimaka; także ogólnie: drożdżówka', świętomarcińskie rogale 'rogale nadziewane masą z białego maku i migdałów, wypiekane na dzień św. Marcina'); odzież, obuwie i dodatki - 133 (np. badejki 'kąpielówki', boba 'czapka, zwłaszcza ciepła, zimowa', hoje 'spodnie', jaczka 'wierzchnie okrycie, marynarka, kaftan' oraz 'kaftanik niemowlęcy', majty 'majtki', naramka 'ramiączko (przy staniku, koszulce itp.)', paputki 'pantofelki domowe, zwykle dziecięce', szabraka 'wierzchnie okrycie (kurtka, marynarka, wdzianko itp.), najczęściej brzydkie', westka 'kamizelka', wzuwanki 'płaskie buciki, czółenka');

ciało - 112 (np. ameryka 'tyłek', dziabara 'nos', fulfa 'pełna, okrągła, nalana twarz', girka 'nóżka', glacuchna 'łysina', gzub 'brzuch', kalafa 'twarz, gęba', kieloch 'ząb', pazura 'ręka', sznupka 'twarz, buzia');

czynności - 105 (np. boksy 'walka bokserska', bręczenie 'marudzenie, zrzędzenie', giglanie 'łaskotanie', kapiółka 'kąpiel', kepówa 'główka, odbicie piłki głową (w piłce nożnej)', knyks 'dziewczęcy ukłon z przygięciem kolana', lofry 'włóczenie się, wałęsanie się', manygowanie 'leniuchowanie, próżnowanie', skiba 'kradzież', sztrykowanie 'robienie na drutach');

przedmioty - 95 (np. bryle 'okulary', deczka 'kocyk, kolderka, narzutka, serwetka', dynks 'jakaś rzecz, której nazwy mówiący nie zna lub w chwili 
mówienia nie pamięta', kałka 'tłuczek do rozcierania ziemniaków', klunkry 'graty, rupiecie, drobiazgi', miech 'worek', mustro 'wykrój, forma, według której kroi się materiał, skórę itp.', szpulotko 'szpulka', tytka 'torebka papierowa', zicherhajtka 'agrafka');

miejsca - 96 (np. fyrtel 'część miasta, dzielnica, kwartał miejski, okolica', gaska 'uliczka, zaułek', góra 'strych', huby 'gospodarstwo lub kilka gospodarstw poza obrębem wsi; też wtórnie domy poza obrębem miasta, peryferie', land 'wieś', ligawa 'ślizgawka', męski pokój 'gabinet', sklep 'piwnica', skład 'sklep', wygnajewo 'przedmieście, pustkowie');

rośliny - 56 (np. chójka 'drzewko iglaste, najczęściej świerczek lub sosenka', gryczpan 'bukszpan', łabuzie 'tatarak', macoszka 'bratek', modrak 'bławatek, chaber', żogówka 'młoda pokrzywa');

zabawy i zabawki - 47 (np. cymbergaj 'gra stołowa przy użyciu monet przesuwanych za pomocą grzebyka', gonito 'zabawa w berka', gruchotka 'grzechotka', pamperek 'pajacyk, maskotka', skryto 'zabawa w chowanego', zając 'wielkanocny zwyczaj obdarowywania dzieci słodyczami, upominkami itp.');

zwierzęta - 45 (np. gajor 'gąsior', hazaj 'zając', kejter 'pies', kociamber 'kot', kokot 'kogut', skop 'baran');

cechy - 45 (np. dalas 'bieda, nędza', drogość 'drożyzna', launa 'dobry humor, nastrój', ruła 'spokój, opanowanie', szajba 'bzik, obłęd', zojcha 'smród');

substancje i materiały - 43 (np. fafoly 'wytrącony osad, męty' oraz 'śmieci, kłęby kurzu', flofry 'męty, osad, zawiesina', mączka 'krochmal', szut 'miał węglowy', zajzajer 'kwas solny', żybura 'brudna, mętna ciecz');

pojazdy - 33 (np. bana 'pociąg', bimba 'tramwaj', kufta 'rower', sportka 'spacerowy wózek dziecięcy', taradeja 'pobłażliwie o pojeździe, dawniej zwłaszcza bryczce, dziś samochodzie', wózik 'wózek');

zbiory (osób, zwierząt lub przedmiotów) - 25 (np. cug 'oddział wojska, pluton', eka 'paczka kumpli, grupa łobuzów, banda młodzieżowa z tej samej części miasta, ulicy, dzielnicy', fiksmatenta 'różności, drobiazgi', glapie wesele 'stado wron lub gawronów w locie', mana 'drużyna sportowa', wiaruchna 'ludzie, ludziska');

instytucje - 16 (np. bezrobocie 'Urząd Pośrednictwa Pracy', byrgerka 'szkoła miejska', gamaja 'gimnazjum', ochronka 'przedszkole (dawniej prowadzone najczęściej przez zakonnice)', samara 'dawniej o seminarium nauczycielskim i duchownym', tejater 'teatr');

mowa - 14 (np. babskie pierdoty 'babskie gadanie', blubry 'brednie, bzdury', klejdry 'plotki', glupoty 'głupstwa, bzdury', klekoty 'gadanina', pierdy 'plotki');

realia szkolne - 14 (np. hista 'historia (przedmiot w szkole)', kateja 'lekcja katechizmu', klacz 'bryk', lekita 'dawniej w gwarze uczniowskiej: lekcja', polewa 'język polski jako przedmiot nauczania w szkole', sekstern 'zeszyt');

dokumenty - 10 (np. flepy 'dokumenty', metryka 'wyciąg z księgi metrykalnej dotyczący urodzin, chrztu', wykaz 'dowód tożsamości');

pogoda - 10 (np. chlabra 'dżdżysta pogoda, plucha', gisówa 'ulewa', parówa 'gorące i wilgotne powietrze'); 
budynki - 8 (np. deska 'długi wielopiętrowy budynek na nowych osiedlach mieszkaniowych', tum 'katedra', willka 'willa');

pieniądze - 8 (np. bejmy 'pieniądze', kapucha 'dużo pieniędzy', piniuchy 'pieniądze');

czas - 7 (np. chwitka 'chwilka', dniówa 'dniówka', podkoziołek 'ostatni dzień karnawału');

varia -60 .

Skłonność przedstawicieli kultury zachodniej do przypisywania obiektom wielu szczegółowych cech widoczna jest także u poznaniaków, co na płaszczyźnie językowej przejawia się w hierarchicznej strukturze poszczególnych kategorii, obejmujących szereg podkategorii. I tak na przykład, w najliczniejszej grupie rzeczowników osobowych wydzielić można między innymi takie podkategorie, jak: nazwy zawodowe, określenia dzieci, kobiet i mężczyzn, nazwy osób odzwierciedlające ich cechy fizyczne i psychiczne, nazwy pokrewieństwa.

Część rzeczowników z gwary miejskiej Poznania to jedynie fonetyczne lub gramatyczne przekształcenia leksemów ogólnopolskich. Wymową różni się 90 regionalnych słów (np. dźwi, gdowa), a 22 leksemy mają inny rodzaj (np. podwórek, selera). Wśród pozostałych rzeczowników regionalnych 695 to formacje pochodne. Dla najliczniejszej grupy derywatów podstawą były rzeczowniki (386, w tym 209 regionalnych), 225 rzeczowników motywowanych jest czasownikami (w tym 110 regionalnymi), 63 przymiotnikami (w tym tylko 10 regionalnymi), pozostałe nieliczne derywaty pochodzą od: wyrażeń przyimkowych (4), liczebników (3) i przysłówków (2 regionalnych), a 13 formacji to composita.

Rzeczowniki z gwary miejskiej Poznania są bazą derywacyjną, jak wyżej wskazano, dla 209 rzeczowników pochodnych oraz dla 102 jednostek językowych należących do innych części mowy (62 czasowników, 45 przymiotników i 7 przysłówków).

Znaczna część opisywanych tu rzeczowników z gwary poznańskiej to słownictwo nacechowane chronologicznie - 635 dawne, przestarzałe lub wychodzące z użycia leksemy to $34,6 \%$ wszystkich rzeczowników. Dziwić może natomiast, stosunkowo mała liczba regionalizmów zabarwionych ekspresywnie 370 jednostek, czyli 19,9\% wszystkich rzeczowników.

\section{Wnioski}

Przeprowadzone w niniejszym artykule analizy i porównania pozwalają sformułować wstępne, bardzo ostrożne wnioski. W świetle koncepcji Richarda E. Nisbetta struktura leksykalna zbliża poznańską polszczyznę regionalną do kultury i języków zachodnioeuropejskich. Widoczne to jest w przewadze rzeczowników, które nazywają obiekty wyróżniane na podstawie wielu szczegółowych cech, co wiąże się $\mathrm{z}$ postawą poznawczą mieszkańców Zachodu, której cechą charakterystyczną jest skłonność do klasyfikowania i kategoryzowania rzeczywistości. Jednakże wspomniany wcześniej „refleks wschodni” bliższy holistycznej wizji świata, w którym ważniejsze są relacje niż obiekty, a widoczny w większym niż w polszczyźnie ogólnej udziale czasowników w strukturze leksykalnej gwary poznańskiej, nieco osłabia powyższe twierdzenie. Zachęca też 
Anna Piotrowicz, Matgorzata Witaszek-Samborska:

Poznańska leksyka regionalna $w$ świetle...

do dalszych badań weryfikujących hipotezę Nisbetta, które powinny być prowadzone $\mathrm{w}$ dwu kierunkach. $Z$ jednej strony należałoby poddać analizie teksty, a nie tylko systemową strukturę leksyki poznańskiej, z drugiej zaś - przyjrzeć się pod tym kątem innym terytorialnym odmianom polszczyzny. 


\section{Bibliografia}

Bańko M., Wyktady z polskiej fleksji, Warszawa (2002)

Gruchmanowa, Walczak (red.), Stownik gwary miejskiej Poznania, wyd. II z suplementem, Warszawa - Poznań (1999)

Kamińska-Szmaj I., Różnice leksykalne między stylami funkcjonalnymi polszczyzny pisanej, Wrocław (1990)

Nisbett R.E., Geografia myślenia, przeł. E. Wojtych, Sopot (2011)

Saloni Z., Struktura gramatyczna stownictwa zawartego w ,Stowniku języka polskiego" pod red. W. Doroszewskiego - zestawienie liczbowe, w: Saloni Z. (red.), Studia z polskiej leksykografii współczesnej, t. I, Wrocław (1988)

Sambor J., Język polski w świetle statystyki, w: Bartmiński J. (red.), Współczesny język polski, Lublin (2001)

Szczyszek M., Słowotwórcze przejawy wspólnoty komunikacyjnej (na przykładzie języka polskiego) (w druku)

Zarębina M., Próba statystycznej analizy słownictwa polszczyzny mówionej (synteza danych liczbowych), Wrocław (1985)

Zgółkowa H., Ilościowa charakterystyka słownictwa współczesnej polszczyzny, Poznań (1987) 